\title{
PERUBAHAN SOSIAL EKONOMI PEKERJA SENTRA INDUSTRI BATIK DI DESA KUNIR KIDUL KECAMATAN KUNIR KABUPATEN LUMAJANG
}

\author{
Rudi Firmansyah \\ Program Studi Pendidikan Ilmu Pengetahuan Sosial, \\ Fakultas Ilmu Sosial, Universitas Negeri Malang \\ E-mail: rudyfirmansyah48@gmail.com
}

\begin{abstract}
ABSTRAK
Industri merupakan bentuk aktivitas ekonomi yang banyak dikembangkan di berbagai wilayah. Di Indonesia sendiri perkembangan Industrialisasi kini telah mengelami perkembangan yang begitu pesat. Tidak hanya di daerah perkotaan saja, melainkan juga dipedesaan sudah di jajaki berbagai kegiatan industri khususnya industri kecil dan menengah (IKM). Tujuan penelitian ini untuk (1) Mendeskripsikan sejarah sentra industri batik di Desa Kunir Kidul, (2) Mendeskripsikan manfaat ekonomi sentra industri batik di Desa Kunir Kidul bagi pekerja, dan (3) Mendeskripsikan perubahan sosial masyarakat pekerja sentra industri batik di Desa Kunir Kidul. Metode penelitian ini menggunakan pendekatan kualitatif dengan analisis deskriptif. Hasil penelitian menunjukkan bahwa sejarah sentra industri batik di Desa Kunir Kidul berawal dari pelatihan membatik kepada masyarakat oleh pelopor usaha batik. Sentra industri batik memberi manfaat bagi masyarakat pekerja, yakni sebagai peluang pekerjaan dan alat untuk meningkatkan ekonomi. para pekerja mayoritas mengalami perubahan sosial, seperti perubahan mata pencaharian, hilangnya status sebagai pengangguran dan berperilaku produktif dari pekerjaan produktif lainnya. Perubahan dari segi ekonomi bahwa para pekerja mengalami peningkatan ekonomi dibandingkan sebelumnya.
\end{abstract}

Kata kunci : Industri, IKM, Sentra Industri Batik Kunir Kidul

\section{PENDAhUlUAN}

Industri Kecil dan Menengah (IKM), memiliki posisi bagian terpenting dari sistem perekonomian nasional (Hubeis, 2009:1). Kegiatan industri kecil sangat memberi andil dalam memajukan pertumbuhan ekonomi dalam suatu negara, membuka peluang usaha dan bisnis baru yang dapat diisi oleh warga sekitar dan para tenaga kerja lain yang ingin bekerja di industri tersebut.

Salah satu sektor Industri Kecil dan Menengah (IKM) yang banyak berkembang di pedesaan adalah Industri Kreatif atau Industri Kerajinan. Industri kreatif merupakan salah satu bidang yang memiliki kedudukan strategis dalam pembangunan, yang dikarenakan kegiatan Industri kerajinan tidak bersifat padat modal melainkan pada padat karya. Artinya usaha dalam Industri kerajinan lebih banyak memanfaatkan tenaga manusia daripada tenaga mesin yang membutuhkan banyak modal untuk menjalankan kegiatan Industri. Fadjar Hutomo Deputi Akses Permodalan Badan Ekonomi Kreatif menyatakan Industri kreatif merupakan sektor keempat terbesar yang menyerap tenaga kerja (Tempo.co, 20 Februari 2017).
Sentra industri batik di Desa Kunir Kidul merupakan Indusri Kecil dan Menengah yang ada di pedesaan. Adanya sentra industri batik di Desa Kunir Kidul tidak hanya sebagai lahan pekerjaan bagi masyarakat di desa kunir kidul maupun diluar desa, melainkan juga sebagai bentuk pemberdayaan bagi masyarakat ekonomi lemah (Ratnasari, 2013:2)

\section{METODE PENELITIAN}

Pendekatan yang digunakan dalam penelitian ini adalah pendekatan kualitatif analis deskriptif. Istilah penelitian kualitatif menurut Kirk dan Muller dalam Kaelan (2011:5) pada awalnya bersumber pada pengamatan kualitatif dengan menekankan pada kuantum atau jumlah, jadi lebih menekankan pada segi kualitas secara alamiah karena menyangkut pengertian, konsep, nilai pada objek yang akan diteliti. Sedangkan analis deskriptif menurut Sugiyono (2015:29) adalah suatu metode yang digunakan untuk menggambarkan atau menganalisis suatu hasil penelitian tetapi tidak digunakan untuk membuat kesimpulan yang lebih luasTujuan dari penelitian deskriptif ini adalah untuk membuat deskripsi, gambaran, atau lukisan secara sistematis, faktual 
dan akurat mengenai fakta-fakta, sifat-sifat serta hubungan antarfenomena yang diselidiki. Dalam hal ini peneliti melakukan penelitian dengan menggambarkan atau mendeskripsikan tentang Perubahan Sosial Ekonomi Pekerja di Sentra Industri Batik Desa Kunir Kidul.

\section{Lokasi Penelitian}

Penelitian ini mengambil subyek di Desa Kunir Kidul Kabupaten Lumajang. Penentuan Lokasi dalam penelitian ini sipilih secara sengaja (Purposive) sebagai syarat dan tujuan penelitian. Pemilihan lokasi ditempatkan di Desa Kunir Kidul yang terdapat sentra industri batik, dimana sentra industri memiliki peran terhadap peningkatan ekonomi masyarakat pekerja khususnya masyarakat sekitar

\section{Sumber Data}

Data merupakan hal yang mutlak digunakan dalam menyusun informasi. Jenis data yang dikumupulkan dan digunakan dalam penelitian adalah data kualitatif. Data kualitatif adalah data yang tidak berupa angka dan cara membaca datanya dengan menjabarkan secara rinci dan jelas agar dapat dimudahkan dalam penarikan kesimpulan. Adapun Sumber data dapat dibedakan menjadi dua yaitu:

a. Data Primer

Sumber data primer merupakan objek penelitian yang diobservasi langsung dengan subjek penelitian yaitu informan. Data yang diperoleh dari informan berupa kata-kata maupun tindakan informan. Teknik pengambilan sampel menggunakan teknik Purposive,artinya informan kunci yang berupa para pekerja yang berjumlah 23 pekerja di industri batik tersebut

\section{b. Data Skunder}

Sumber data sekunder merupakan data yang diperoleh secara tidak langsung di lapangan, melainkan hasil dari studi pustaka maupun studi dokumentasi terhadap berbagai rujukan maupun arsip (rekaman video aktivitas pekerja di industri batik) yang mendukung dalam topik pembahasan dalam penelitian ini guna lebih memahami secara mendalam tentang permasalahan yang dijadikan sebagai objek penelitian. arsip tersebut berupa perkembangan Adapun juga owner sebagi informan pendukung yang dapat memperkaya data.

\section{Teknik Pengumpulan Data}

a. Observasi

Observasi adalah pengamatann dan pencatatan dengan sistematik atas fenomenafenomena yang telah diselidiki. Observasi yang dilakukan untuk mendapatkan data dan gambaran lebih mendalam tentang aspek yang diteliti. Menurut Patilima (2005:69). Teknik observasi digunakan untuk menggali data dari sumber data yang berupa peristiwa, tempat atau lokasi, dan benda serta rekaman gambar. Observasi dapat dilakukan secara langsung maupun tidak langsung.Observasi secara langsung dilakukan secara langsung dengan mengambil peran ataupun tidak berperan (Hasan, 2002:128). Observasi dengan tidak mengambil peran peneliti sama sekali, kehadiranya ketika observasi tidak diketahui oleh subyek yang diamati, maka dari itu peneliti dapat mengetahui kondisi subyek menurut apa adanya. Adapun data yang diperoleh dari hasil observasi antara lain data sejarah sentra industri batik di kunir kidul, manfaat ekonomi dan tipologi masyarakat pekerja.

b. Wawancara

Wawancara digunakan sebagai teknik pengumpulan data apabila peneliti ingin melakukan studi pendahuluan untuk menemukan permasalahan yang harus diteliti, dan juga apabila peneliti ingin mengetahui hal-hal dari responden yang lebih mendalam dan jumlah respondenya sedikit (Sugiyono,2015:194). Percakapan wawancara dilakukan oleh dua pihak yaitu pewancara yang mengajukan pertanyaan dan responden yang menjawab pertanyaan tersebut atau pemberi informasi yang dibutuhkan oleh peneliti.

Teknik wawancara dalam penelitian ini menggunakan teknik Wawancara tertruktur. Wawancara terstruktur merupakan cara yang digunakan sebagai teknik pengumpulan data. Ketika menggunakan wawancara tertruktur, peneliti telah menyiapkan instrument penelitian berupa pertanyaan-pertanyaan tertulis. Dengan wawancara tertruktur ini, setiap informan diberi pertanyaan sama, dan pengumpul data mencatatnya selain itu pengumpul data dapat menggunakan beberapa pewawancara dengan memberikan training terlebih dahulu agar memili persepsi yang sama (Sugiyono, 2015:195). Adapun data yang diperoleh dari hasil wawancara antara lain tentang sejarah sentra industri batik di kunir kidul, manfaat ekonomi dan tipologi masyarakat pekerja.

c. Dokumentasi

Dokumentasi sangat penting karena untuk menambah informasi dan pengetahuan yang 
Focus: Jurnal

Pekerjaan Sosial

disampaikan oleh narasumber atau informan. Dokumentasi ini bisa berupa dokumen publik (seperti Koran, makalah, laporan) ataupun dokumen privat seperti buku harian, diary dan email (Creswell, 2014:270). Adapun dokumentasi pada penelitian ini akan di peroleh dokumentasi berupa arsip tentang sejarah sentra idustri batik di kunir kidul, foto pekerja industri batik, foto wawancara dengan informan.

\section{Analisis Data}

Analisis data merupakan proses berkelanjutan yang membutuhkan refleksi secara terus - menerus terhadap data, mengajukan pertanyaan-pertanyaan analitis, dan menulis catatan singkat sepanjang penelitian. Railis dalam Creswell, (2014:274) menyatakan bahwa analisis data melibatkan data yang terbuka dan didasarkan oleh pertanyaan - pertanyaan umum serta analisis informasi dari para partisipan.

Analisis data kualitatif akan mengusut sampai tuntas dan data sampai jenuh. Adapun aktivitas dalam analisis data sebagai berikut:

\section{a. Pengumpulan Data}

Pengumpulan data dilakukan sepanjang penelitian berlangsung sejak observasi awal, wawancara awal, observasi selama persiapan hingga pelaksanaan, wawancara mendalam sampai data yang diperlukan peneliti telah terpenuhi.

\section{b. Reduksi Data}

Mereduksi data berarti merangkum, memilih hal-hal pokok, memfokuskan pada hal- hal yang penting, dicari tema dan polanya. Dengan demikian data yang telah direduksi akan memberikan gambaran yang lebih jelas dan mempermudah peneliti untuk melakukan pengumpulan data selanjutnya serta mencarinya bila diperlukan. Kaitannya dengan pelaksanaan analisis data dalam penelitian yang dilakukan di Industri batik Desa Kunir Kidul, hal yang perlu dilakukan ialah mencatat data yang diperoleh dilapangan, kemudian mereduksi data yang terkumpul dan menyimpulkannya.

c. Penyajian Data

Sekumpulan informasi tersusun yang memberi kemungkinan adanya penarikan kesimpulan dan pengambilan tindakan (Miles \& Huberman, 1992:19). Dalam penelitian kualitatif, penyajian data berbentuk uraian singkat, bagan, hubungan antar kategori, flowchart dan sejenisnya. Yang paling sering digunakan untuk menyajikan data dalam penelitian kualitatif adalah dengan teks naratif.

\section{d. Penarikan Kesimpulan}

Langkah terakhir menurut Miles dan Huberman adalah penarikan kesimpulan dan verifikasi. Kesimpulan awal yang dikemukakan masih bersifat sementara, dan akan berubah bila tidak ditemukan bukti-bukti yang kuat dan mendukung pada pengumpulan data berikutnya. Tetapi apabila kesimpulan yang dikemukakan pada tahap awal, didukung oleh bukti-bukti yang valid dan konsisten saat peneliti kembali ke lapangan mengumpulkan data, maka kesimpulan yang dikemukakan merupakan kesimpulan yang kredibel. Kesimpulan diharapkan adanya temuan baru yang sebelumnya belum pernah ada (Prastowo, 2012:248)

\section{PEMBAHASAN}

\section{Sejarah Sentra Industri Batik di Desa Kunir Kidul}

Sentra industri batik Kunir Kidul muncul pasca perkembangan IKM di seluruh Indonesia, tepatnya sebelum krisis moneter. Nurainun dkk (2008:123) mengatakan bahwa Perkembangan IKM di Indonesia terjadi pada masa sebelum krisis moneter 1997, Pada masa tersebut banyak bermunculan IKM di berbagai daerah (Nurainun dkk, 2008:123). Kemunculan sentra industri batik Kunir Kidul bermula pada pelatihan membatik oleh pelopor usaha batik kepada masyarakat. Hal ini merupakan inisiatif aparat desa. Tujuan dari inisitaif tersebut adalah menjadikan masyarakat di Karang Taruna menjadi trampil. Menurut Arisandy (2015:149) bahwa menjadi terampil akan memberi pengaruh positif terhadap perkembangan karir.

Pada 6 september 1992 sentra industri batik di Kunir Kidul di bentuk. Pembentukan usaha tersebut merupakan proses awal pengembangan usaha batik yang diberi nama Makarti Jaya. Sentra industri batik ini merupakan IKM kreatif yang membutuhkan ketelitian dan kreatifitas dalam proses produksinya. Sesuai dengan teori Merdekawati (2016:61) bahwa sentra usaha batik tergolong dalam kelompok Industri Kecil dan Menengah yang menghasilkan produk berbasis kebudayaan dan kreativitas.

IKM batik Makarti Jaya tergolong usaha baru pada waktu itu. Sehingga sering terjadi proses pengembangan produk secara terus menerus. Pengembangan produk dilakukan untuk menghasilkan produk yang bagus dan berkualitas. Tujuannya adalah agar dapat bersaing dengan produk lain yang ada di pasaran. Menurut Konadi dan Irawan(2016:66) bahwa usaha yang tergolong baru hakekatnya mengarah pada pengembangan 
Focus: Jurnal

Pekerjaan Sosial

usaha yang menuntut wirausaha untuk berani menanggung resiko demi terciptanya suatu tujuan. Seiring berjalannya waktu perkembangan sentra usaha batik Makarti Jaya bertambah baik. Pada tahun 1994 usaha batik mengalami peningkatan fasilitas produksi yang diakibatkan melonjaknya jumlah pesanan dari berbagai lembaga sekolah dasar. Perkembangan ini tidak lepas dari ketekunan dan kegigihan pemilik usaha dalam menghadapi berbagai tantangan untuk memajukan sentra industri batik. Hal ini sesuai dengan teori Nurseto (2004:99) yang mengatakan bahwa seorang wirausaha harus banyak akal dan tidak mudah putus asa, ia harus selalu bangkit dan tekun.

\section{Manfaat Ekonomi Sentra Industri Batik di Desa Kunir Kidul Bagi Pekerja}

Keberadaan sentra industri batik sebagai IKM memberikan manfaat bagi masyarakat. Manfaat yang pertama, terbukanya lapangan pekerjaan. Widodo (2011:42) mengatakan bahwa lapangan pekerjaan adalah kebijakan kesempatan kerja yang dapat menyerap tenaga kerja. Penyerapan tenaga kerja ini berguna untuk melakukan kegiatan produktifitas pada lapangan pekerjaan tesebut. Peluang inil dapat dimanfaatkan oleh masyarakat, sehingga masyarakat memperoleh penghasilan sesuai yang mereka harapkan.

Kedua, sebagai alat bantu meningkatan ekonomi keluarga. Sentra industri batik memberi kesempatan para wanita untuk dapat bekerja. Hal tersebut menjadikan mereka memiliki kesempatan menjadi pekerja, sehingga berpeluang meningkatkan ekonomi keluarga. Mereka melakukan upaya peningkatan ekonomi keluarga untuk memanajemen kebutuhan ekonomi guna memperoleh kesejahteraan keluarga. Upaya wanita untuk meningkatkan ekonomi keluarga ini menurut Aswiyati (2016:3) adalah peranan dan sumbangsih secara aktif dalam pembangunan dan menunjang perekonomian keluarga. Faktor yang menjadikan wanita mampu bekerja dan meningkatkan ekonomi keluarga adalah fleksibelitas kerja sentra industri batik. Sentra industri batik memberi kemudahan jam kerja kepada mereka, supaya dapat berpartisipasi di dalamnya. Selvaratnam dan Yeng (2011:87) menjeaskan bahwa kebijakan fleksibelitas kerja oleh perusahaan mengacu pada waktu kerja yang anjal untuk individu supaya dapat menyesuaikan dirinya dalam menyumbangkan tenaga kerjanya.

\section{Perubahan Sosial Ekonomi Masyarakat Pekerja Sentra Industri Batik di Desa Kunir Kidul}

Perubahan sosial masyarakat Menurut Soekanto (2012:263) terjadi karena adanya perubahan unsur-unsur yang mempertahankan keseimbangan masyarakat seperti perubahan unsur ekonomis dan kebudayaan. Masyarakat Desa Kunir Kidul dan sekitarnya mengalami perubahan pasca adanya sentra industri batik. pertama, hilangnya status sebagai pengangguran. Hal ini dikarenakan masyarakat pengangguran mampu memanfaatkan peluang kerja yang ditawarkan sentra industri batik. Masyarakat yang seperti ini menurut Bryant dalam Doriza (2015:7) adalah tipe masyarakat yang mampu mengatur kehidupannya, mengorganisasi diri dalam upaya mencapai kehidupan yang lebih baik.

Kedua, masyarakat mengalami perubahan mata pencaharian. Perubahan mata pencaharian tersebut terjadi dari beberapa pekerjaan hingga memilih menjadi pekerja di sentra industri batik. Faktor perubahan mata pencaharian ini didasari atas perilaku individu untuk melakukan alternatif pekerjaan lain yang lebih menguntungkan. Menurut Ferlianto (2014:49) bahwa setiap pekerja akan berpindah pekerjaan yang mengacu pada hasil evaluasi individu, jika perusahaan belum mampu memberi keuntungan bagi pekerja dalam tindakannya.

Ketiga, perubahan pada perilaku produktif oleh masyarakat. Pengaruh fleksibelitas kerja oleh sentra industri batik, membuat pekerja wanita melakukan pekerjaan produktif di sela pekerjaan produktif lainnya. Hal ini merupakan suatu peran ganda yang dilakukan oleh mereka. Menurut Salaa(2015:17) bahwa seorang wanita(ibu-ibu rumah tangga) yang melakukan pekerjaan diluar rumah artinya melakukan peran ganda sebagai isteri dan ibu, tetapi juga berperan sebagai pencari nafkah untuk membantu meningkatkan perekonomian keluarga.

Perubahan yang dilakukan masyarakat, berpengaruh pada peningkatan ekonomi. Pendapatan ekonomi masyarakat mengalami peningkatan. Hal ini terjadi melalui perubahan pekerjaan dan perilaku produktif untuk meningkatkan ekonomi. Mereka mendapatkan penghasilan yang lebih tinggi dibandingkan pekerjaan sebelumnya dan mendapat tambahan penghasilan bagi para wanita dari aktivitas produktif yang lain, yakni di sentra industri batik. Dengan demikian sentra industri batik di Desa Kunir Kidul telah melaksanakan peran dan 
fungsinya sebagai IKM yang berguna untuk memberdayakan ekonomi masyarakat. Ratnasari (2013:2) mengatakan bahwa sub sektor IKM memiliki peran dan fungsi sebagai bentuk pemberdayaan terhadap masyarakat ekonomi lemah dan meningkatkan taraf ekonominya.

\section{KESIMPULAN DAN SARAN}

\section{A. KESIMPULAN}

Sentra industri batik di Desa Kunir Kidul didirikan Pada tangal 6 september 1992 yang diberi nama Makarti Jaya. Kemunculannya bermula pada pelatihan membatik kepada masyarakat di Karang Taruna yang dilakukan oleh seorang pelopor usaha batik. Pelatihan membatik ini merupakan atas dasar inisitif Kepala Desa. Pada tahun 1994 usaha batik Makarti Jaya mengalami peningkatan fasilitas produksi, setelah mendapat banyak pesanan dari berbagai lembaga sekolah dasar

Manfaat ekonomi sentra industri batik di Desa Kunir Kidul bagi pekerja yakni Memberi lapangan pekerjaan bagi masyarakat pekerja. masyarakat pekerja memanfaatkan peluang tersebut untuk mendapatkan pekerjaan dan penghasilan. Manfaat lainnya yakni sebagai alat bantu meningkatkan ekonomi keluarga pekerja. Peningkatan ekonomi keluarga ini banyak dilakukan oleh para wanita yang merupakan ibuibu rumah tangga.

Perubahan sosial ekonomi masyarakat pekerja di sentra industri batik, Berdasarkan dampak sosialnya terjadi perubahan yakni, 1) hilangnya status sebagai pengangguran, 2) terjadinya perubahan mata pencaharian dan, 3) perubahan perilaku produktif oleh masyarakat pekerja wanita. Sedangkan dari segi ekonomi para pekerja telah mengalami peningkatan ekonomi.

\section{B. SARAN}

Dari rumusan masalah dan hasil penelitian maka peneliti dapat memberikan saran agar sentra industri batik di Desa Kunir Kidul terus dikembangkan hingga menjadi usah batik sekala besar. Dengan demikian maka akan banyak masyarakat yang diserap

\section{DAFTAR PUSTAKA}

Arisandy, M.R. 2015. Pengaruh Keterampilan dan Pengalaman Kerja Terhadap Pengembangan Karir Pegawai Pada Dinas Pendidikan Kabupaten Donggala. Jurnal Katalogis, 3(8), 149.
Aswiyati, Indah. 2016. Peran Wanita dalam Menunjang Perekonomian Rumah Tangga Keluarga Petani Tradisional untuk Penanggulangan Kemiskinan di Desa Kuwil Kecamatan Kalawat. Jurnal Holistik, 9(17), 3.

Creswell, Jhon W. 2014. Penelitian Kualitatif dan Desain Riset. Yogyakarta: Pustaka Pelajar.

Doriza, Hinata. 2015. Ekonomi Keluarga.Bandung: PT Remaja Rosdakarya.

Ferlianto. 2014. Pengaruh Kepuasan Gaji, Shift Kerja Malam dan Kepuasan Kerja Terhadap Intensi Keluar Karyawan (Studi Pada Call Center Pt Vads Indonesia Kantor Cabang Yogyakarta). Jurnal Ekonomi, 11(2).

Hasan, M. Iqbal. 2002. Pokok-pokok Materi Metodologi Penelitian dan Aplikasinya. Bogor: Ghalia Indonesia.

Hubeis, Musa. 2009. Prospek Usaha Kecil dalam Wadah Inkubator Bisnis. Jakarta: Ghaila Indonesia.

Kaelan. 2011. Metode Penelitian Kualitatif Interdisipliner. Yogyakarta Paradigma.

Konadi, W dan Irawan, D. 2016. Tinjauan Konseptual Kewirausahaan Dalam Bisnis Pembentukan Wirausaha Baru Untuk Mengatasi Pengangguran. Jurnal Ekonomi, 3(5), 66.

Miles, Matthew B. \& Huberman, A Michael. 1992. Analisis Data Kualitatif: Buku Sumber Tentang Metode-metode Baru. Terjemahan Rohidi, Tjejep Rohendi. Jakarta: Universitas Indonesia Pers.

Merdekawati. 2016. Kesesuaian Sentra Industri Batik Masaran Kabupaten Sragen Sebagai Sentra Industri Kreatif Kerajinan. Jurnal Teknik, 7(2), 61.

Nurainun., Heriyana., Rasyimah. 2008.Analisis Industri Batik di Indonesia.Jurnal Ekonomi, 7(2), 123-124.

Nurseto, Tejo. 2014. Strategi Menumbuhkan Wirausaha Kecil Menengah Yang Tangguh. Jurnal Ekonomi dan Pendidikan, 1(1),99.

Patilima, H. 2005. Metode Penelitian Kualitatif. Bandung: Alfabeta.

Prastowo, Andi. 2012. Panduan Kreatif Membuat Bahan Ajar Inovatif. Yogyakarta: Diva Press.

Ratnasari, Andri. 2013. Peranan Industri Kecil Menengah (Ikm) dalam Penyerapan Tenaga Kerja di Kabupaten Ponorogo. Jurnal Pendidikan Ekonomi, 1(3), 2.

Soekanto, Soerjono. 2012. Sosiologi Suatu Pengantar. Jakarta: PT Raja Grafindo Persada.

Salvaratnam, D.P dan Yeng, K.K. 2011. Peranan Wanita dalam Pasaran Kerja Fleksibel di 
Malaysia: Kajian Kes di Sektor Perkhidmatan. Jurnal Ekonomi, ISSN: 2231962X.

Salaa, Jeiske. 2015. Peran Ganda Ibu Rumah Tangga dalam Meningkatkan Ekonomi Keluarga di Desa Tarohan Kecamatan Beo Kabupaten Kepulauan Talaud. Jurnal Holistik, 8(15), 17.

Sugiyono. 2015. Metode Penelitian Kuantitatif Kualitatif dan R\&D. Bandung: Alfabeta.

Tempo.co. 2017. Industri Kreatif Bertumbuh 5 Persen Setiap Tahun. (Online), (https://www.bisnis.tempo.co/read/867 872/industri-kreatif-bertumbuh-5 persensetiap-tahun) diakses 20 Desember 2017.

Widodo, Budiman. 2011. Kebijakan Kesempatan Kerja. Jurnal Ilmu Administrasi Negara, 11(1), 4. 